\title{
Perceived barriers for active commuting to school among adolescents from Curitiba, Brazil
}

\author{
Barreiras percebidas para o deslocamento ativo para a escola entre os \\ adolescentes de Curitiba, Brasil
}

Leonardo Augusto Becker1,2, Rogério César Fermino ${ }^{1,4}$, Alex Vieira Lima ${ }^{1}$, Cassiano Ricardo Rech 1,5, Ciro Rome lio Rodriguez Añez ${ }^{1,4}$, Rodrigo Siqueira Reis ${ }^{1,2,3}$

\begin{abstract}
The aim of this study was to analyze the association between perceived barriers for active commuting to school in the form of displacement of adolescents from Curitiba, Brazil. Interviews were conducted in six schools (three public and three private) with 741 adolescents aged 11-18 yrs. Perceived barriers for active commuting were assessed through a questionnaire with seventeen questions. Active commuting was defined as walking or bicycling to or form school at least one day per week. The associations were tested by Poisson regressions with $5 \%$ significance level. The prevalence of active commuting was of $42.9 \%$ (50.0\% in boys and $37.2 \%$ in girls, $\mathrm{p}<0,001)$. For boys the barriers: "It is too far" (RP: 0.71; 95\%CI: 0.60- 0.86), "Route as boring" (RP: 1.30; 95\%CI: 1.04-1.62) and "Too much traffic" (PR: 1.27; 95\%CI: 1:04 to 1:56) were associated with active commuting. For girls, the barriers: "It is easier to go by car or bus" (RP: 0.70 ; 95\%CI: 0.56-0.88) and involve "It requires too much planning" (RP: 0.60; 95\%CI: 0.42-0.86) were associated with active commuting. Environmental and psychological barriers were associates with active commuting among adolescents to school. Efforts to promote active commuting, should consider gender specific actions. Providing safe routes and organize group activities for girls, and indicate faster routes for boys could help increasing this behavior among adolescents.
\end{abstract}

\section{Keywords}

Architectural Accessibility; Adolescents; Motor Activity; Cross-Sectional Studies; Brazil.

\section{Resumo}

O objetivo desse estudo foi analisar a associação entre as barreiras percebidas para o deslocamento ativo com a forma de deslocamento para a escola em adolescentes de Curitiba, Brasil. Foram entrevistados 741 adolescentes com idade entre 11-18 anos em seis escolas (três públicas e três privadas). A percepção de barreiras para o deslocamento ativo para escola foi avaliado por uma escala com 17 itens. O deslocamento ativo para escola foi considerado quando o adolescente relatou ir ou voltar da escola caminhando ou andando de bicicleta em ao menos um dia na semana. A associação foi testada com a regressão de Poisson e o nivel de significância mantido em 5\%. A prevalência de deslocamento ativo foi de 42,9\% (50,0\% meninos e 37,2\% meninas $p<0,001$ ). Para os meninos, as barreiras associadas com o deslocamento ativo foram: "Morar longe da escola" (RP: 0,71; IC95\%: 0,60-0,86), identificar o "Percurso como chato" (RP: 1,30; IC95\%: 1,04-1,62) e "Muito tráfego" (RP: 1,27; IC95\%: 1,04-1,56). Para as meninas, perceber que é "Mais fácil ir de carro/ ônibus" (RP: 0,70; IC95\%: 0,56-0,88) e envolver "Muito planejamento" (RP: 0,60; IC95\%: 0,42-0,86) foram associadas ao deslocamento ativo. Barreiras ambientais e psicológicas apresentaram-se associadas com deslocamento ativo para a escola entre adolescentes. Os esforços para promover o deslocamento ativo devem considerar ações específicas a cada sexo. Proporcionar rotas seguras e organizar atividades em grupo para as meninas e indicar rotas mais rápidas podem ser maneiras de aumentar esse comportamento em adolescentes.

\section{Palavras-chave}

Estruturas de acesso; Adolescente; Atividade motora; Estudos transversais; Brasil.
1 Pontifical University Catholic of Paraná. Research Group in Physical Activity and Quality of Life (GPAQ). Curitiba-PR. Brazil.

2 Federal University of Paraná. Postgraduate Program in Physical Education. CuritibaPR. Brazil.

3 Washington University in St. Louis. Brown School. Prevention Research Center. St. Louis, United States

4 Federal University of Technology - Paraná. Post-Grauate Program in Physical Education. Research Group in Environment, Physical Activity and Health (GPAAFS).

5 Federal University of Santa Catarina. Postgraduate Program in Physical Education. Florianópolis-SC. Brazil.

\section{Introduction}

Active commuting to school is an important strategy to increase physical activity and health in adolescents ${ }^{1,2}$. In high-income countries, as United States, Canada and Belgium, the prevalence of active commuting ranges from $50-68 \%^{2-4}$ whereas in Brazil, despite the limited evidence, the prevalence is somehow similar to high-income countries (49-63\%) 
Overall, individual correlates of active commuting are also similar across countries $^{5-8}$. For instance, age, income and the number of perceived barriers are with less active community in both high and low-to-middle income countries ${ }^{9}$. However, the evidence on the barriers to active commuting in adolescents is just beginning to emerge and only few studies have been conducted in low and middle-income countries, specifically in the Latin America region ${ }^{10}$. In fact, to this date only three studies have been conducted in Latin America ${ }^{11-13}$ and found that active commuting to school was associated with gender (boys), age (12-16 years old), place of residence (urban), travel time ( $<15$ minutes) and family income $(<\mathrm{R} \$ 1,000)^{5,6}$.

To this date only one study explored correlates perception with active commuting in Brazilian adolescents ${ }^{13}$ and showed that active commuting was lower among students of private schools, those who spent $>20$ minutes to commute, and those that spent more time watching television. The correlates with active commuting were short distance, low crime perception and light traffic ${ }^{13}$.

The evidence on perceived barriers for active commuting among adolescents in Brazil is limited and nearly all the evidence on this subject is from high-income countries ${ }^{2-4,9}$. Additionally, the built and social environment characteristics in Brazil, as in other upper-middle income countries, are different when compared from high-income countries (e.g. bicycling infrastructure, traffic congestion, safety from crime $)^{14}$. Hence, the use of the available evidence to help guide policies and environmental changes to promote active commuting in Brazilian adolescents is prevented by the lack of contextual characteristics. The aim of this study was to analyze the association between perceived barriers for active commuting to school with the form of displacement of adolescents from Curitiba, Brazil.

\section{Methods}

\section{Participants and data collection}

This study was conducted in public and private schools of Curitiba, Brazil, between August and November 2012. The information hereby used was extracted from a database originally obtained though a pilot project ${ }^{15}$ as part of a cross-sectional, epidemiological and international study, called International Physical Activity and Environment Network (IPEN), which is being held in 19 countries, and has the city of Curitiba representing Brazil. Curitiba is located in the south of the Brazil with approximately 1.8 million inhabitants and it's classified as a city of moderate to high quality of life as defined by the Human Development Index $=0.800$. All procedures have been approved by the Ethics Committee for Research with humans of the Pontifical Catholic University of Parana (93.664/12).

The sampling was performed in two stages. First, six schools (three public and three private) were selected by convenience in order to discriminate level of socioeconomic status according with the geographic position and income of the neighbourhoods where they were located. Secondly, within each school one-grade classroom was randomly selected until the number of subjects necessary to represent the school was achieved (seven classrooms in each school). All students in the selected classes were considered eligible for this study. Data collection was conducted in each classroom by three researchers. For this study 800 adolescents were eligible, and the final sample included 741 adolescents (55.5\% girls; $7.4 \%$ of losses).

The sample power was estimated a posteriori for Poisson regression analyzes and estimated associations of at least 1.10 and effect of 0.5 . According to these estimators sample power was of 0.92 . 


\section{Outcome variable: active commuting to school}

The outcome variable was assessed by asking students about the mode of commuting used to go to and from school during a typical week (e.g. walking, bicycling, public or private motorized transportation). All students who reported walking or bicycling to go to and from school were classified as "active commuters". This question showed adequate test-retest reliability (walking, CCI=0.90; $\mathrm{p}<0.05$; and bicycling, CCI $=0.95 ; \mathrm{p}<0.05$ ) and it has been use $\mathrm{d}$ in similar studies ${ }^{2,7}$.

\section{Independent variable: barriers for active commuting to school}

The explanatory covariate variables were assessed as perceived barriers for active commuting to school and included seventeen questions that emphasized personal, social and environmental barriers (e.g. lack of motivation, company, social support and safety from crime). All items were adapted from existing surveys $s^{3,7,9,13,16-19}$.

The adolescents informed their perception using a four points scale, ranging from 1 (strongly disagree) to 4 (strongly agree) when asked "How difficult is to walk or bike to school?" for the following questions "It is easier to go by car/bus", "There are dangerous crossings", "There is too much traffic", "I have too many things to carry", "It is too far", "There are too many hills", "The route is boring", "I get hot and sweat a lot", "I don't like walking or riding a bike", "It's not cool to walk or ride a bike to school", "There are no other teenagers on the way", "There are dogs on the street", "Lack of bike lanes", "I would have to go through unsafe places", "There is no place to leave a bike safe", "It involves too much planning", "The route does not have good lighting".

The responses were categorized into dichotomous variables and the original categories "agree" and "strongly agree" were combined and considered "presence of barriers".

\section{Confounding variables: sociodemographic, distance to school and physical activity}

Covariates also included the following sociodemographic variables: gender (boy and girl), age (11-14 vs. 15-18 years old), type of school (public vs. private), parents schooling (up to elementary school, higher school, undergraduate) ${ }^{21}$ and perceived distance time from home to school ( $\leq 10 \mathrm{~min} ., 11-20 \mathrm{~min} ., 21-30 \mathrm{~min}$. , and $\geq 31 \mathrm{~min}$ ). Physical activity practices in leisure time were reported by frequency (days/week) and duration (minute/day) of moderate-to-vigorous physical activity. Adolescents that reported practicing $\geq 300 \mathrm{~min} /$ week were classified as "active" 20 .

\section{Data analyses}

Data were summarized and presented through descriptive statistics (absolute and relative frequency distributions). Initially, the most frequent barriers were identified, and stratified by gender. Frequency of active commuting was stratified by categories of perceived barriers. The association between active commuting and number of barriers were tested with linear trend chi-square tests $\left(x^{2}\right)$.

The associations between the independent variables (presence of barriers) and the outcome (active commuting) were tested through crude and adjusted Poisson regressions, stratified by gender. For the adjusted analysis, all possible covariables and barriers were inserted at the same level by the forced entry method, and only those with $\mathrm{p} \leq 0.20$ were retained in the final model. Analyses were conducted in STATA 12.0 with a significance level of $5 \%$. 


\section{Results}

The final sample included 741 adolescents $(55.5 \%$ girls) most of them were of 11 14 years old (51.4\%), enrolled in private schools $(60.1 \%)$ and had at least one parent with less than undergraduate level of schooling (51.0\%). The prevalence of active adolescents in leisure time was 19.7\%; and 43.0\% reported living at least 30 minutes or more walking to or from school. The prevalence of active commuting to school was of $42.9 \%$ (50.0\% in boys and $37.2 \%$ in girls, $\mathrm{p}<0.001)$ (Table 1 ).

TABLE 1 - Descriptive characteristics of participants by gender. Curitiba, Brazil, 2012 ( $n=741)$.

\begin{tabular}{|c|c|c|c|c|c|c|c|}
\hline & \multicolumn{2}{|c|}{$\begin{array}{c}\text { Boys } \\
(n=330 ; 44.5 \%)\end{array}$} & \multicolumn{2}{|c|}{$\begin{array}{c}\text { Girls } \\
(n=411 ; 55.5 \%)\end{array}$} & \multirow[t]{2}{*}{ p } & \multicolumn{2}{|c|}{$\begin{array}{c}\text { All } \\
(n=741 ; 100 \%)\end{array}$} \\
\hline & $n$ & $\%$ & $n$ & $\%$ & & $n$ & $\%$ \\
\hline \multicolumn{8}{|l|}{ Age } \\
\hline $11-14$ yrs old & 162 & 42.5 & 219 & 57.5 & 0.256 & 381 & 51.4 \\
\hline 15-18 yrs old & 168 & 46.7 & 192 & 53.3 & & 360 & 48.6 \\
\hline \multicolumn{8}{|l|}{ Type of school } \\
\hline Public & 139 & 42.2 & 157 & 36.9 & 0.279 & 296 & 39.9 \\
\hline Private & 191 & 57.8 & 254 & 63.1 & & 445 & 60.1 \\
\hline \multicolumn{8}{|c|}{ Schooling of a parent/responsible } \\
\hline Up to elementary school & 12 & 3.6 & 20 & 4.8 & 0.206 & 32 & 4.3 \\
\hline High school & 142 & 43.0 & 189 & 45.9 & & 331 & 44.7 \\
\hline Undergraduate & 176 & 53.4 & 202 & 49.3 & & 378 & 51.0 \\
\hline \multicolumn{8}{|c|}{ Physical activity in leisure-time } \\
\hline$<300 \mathrm{~min} / \mathrm{wk}$ & 240 & 72.7 & 355 & 86.3 & $<0.001$ & 595 & 80.3 \\
\hline$\geq 300 \mathrm{~min} / \mathrm{wk}$ & 90 & 27.3 & 56 & 13.7 & & 146 & 19.7 \\
\hline \multicolumn{8}{|c|}{ Perceived distance walking to school } \\
\hline$\leq 10 \min$ & 76 & 23.0 & 80 & 19.5 & 0.486 & 156 & 21.1 \\
\hline $11-20 \mathrm{~min}$ & 68 & 20.6 & 73 & 17.8 & & 141 & 19.0 \\
\hline $21-30 \mathrm{~min}$ & 46 & 13.9 & 82 & 19.9 & & 128 & 17.3 \\
\hline$\geq 31 \mathrm{~min}$ & 140 & 42.5 & 176 & 42.8 & & 316 & 42.6 \\
\hline \multicolumn{8}{|l|}{ Active commuting to school* } \\
\hline No & 165 & 50.0 & 258 & 62.8 & $<0.001$ & 423 & 57.1 \\
\hline Yes & 165 & 50.0 & 153 & 37.2 & & 318 & 42.9 \\
\hline
\end{tabular}

* walking or bicycling.

The most frequently reported barriers were convenience to use car/bus ("It is easier to go by car/bus", boys: $74.5 \%$; girls $80.8 \%$ ), unsafe to crossings ("Dangerous crossings", boys: 64.2\%; girls: 73.2\%) and traffic ("Too much traffic”, boys: 61,2\%; girls: 72.5\%). The least reported were, the route does not good ("Not enough lighting", boys: 20.6\%; girls: 24.1\%), much planning ("It involves too much planning", boys: 21.8\%; girls: 28.5\%), and through unsafe place ("Unsafe places", boys: 26.4\%; girls: $36.7 \%)$. With exception of the barrier "There are dog on the street", all others were more frequently reported by girls (Figure 1).

The inverse association was verified between the number of barriers and active commuting to school in adolescents $(\mathrm{p}<0.001)$ (Figure 2$)$. Similar results were found when analyses were stratified by gender (data no show).

In the crude analysis, eight barriers were associated with active commuting to school among boys (Table 2) and girls (Table 3). After adjusted for confounding variables, three barriers remained associated with active commuting among boys, and two among girls. In boys the barrier "It is too far" (PR: 0.71; 95\%CI: 0.60-0.86), 
"There is too much traffic" (PR: 1.27; 95\%CI: 1.04-1.56) and "The route is boring" (PR: 1.30; 95\%CI: 1.04-1.62) (Table 2). In girls "It is easier to go by car or bus" (PR: 0.70; 95\%CI: 0.56-0.88) and "It requires too much planning" (PR: 0.60; 95\%CI: 0.42-0.86) were associated with active commuting to school (Table 3 ).

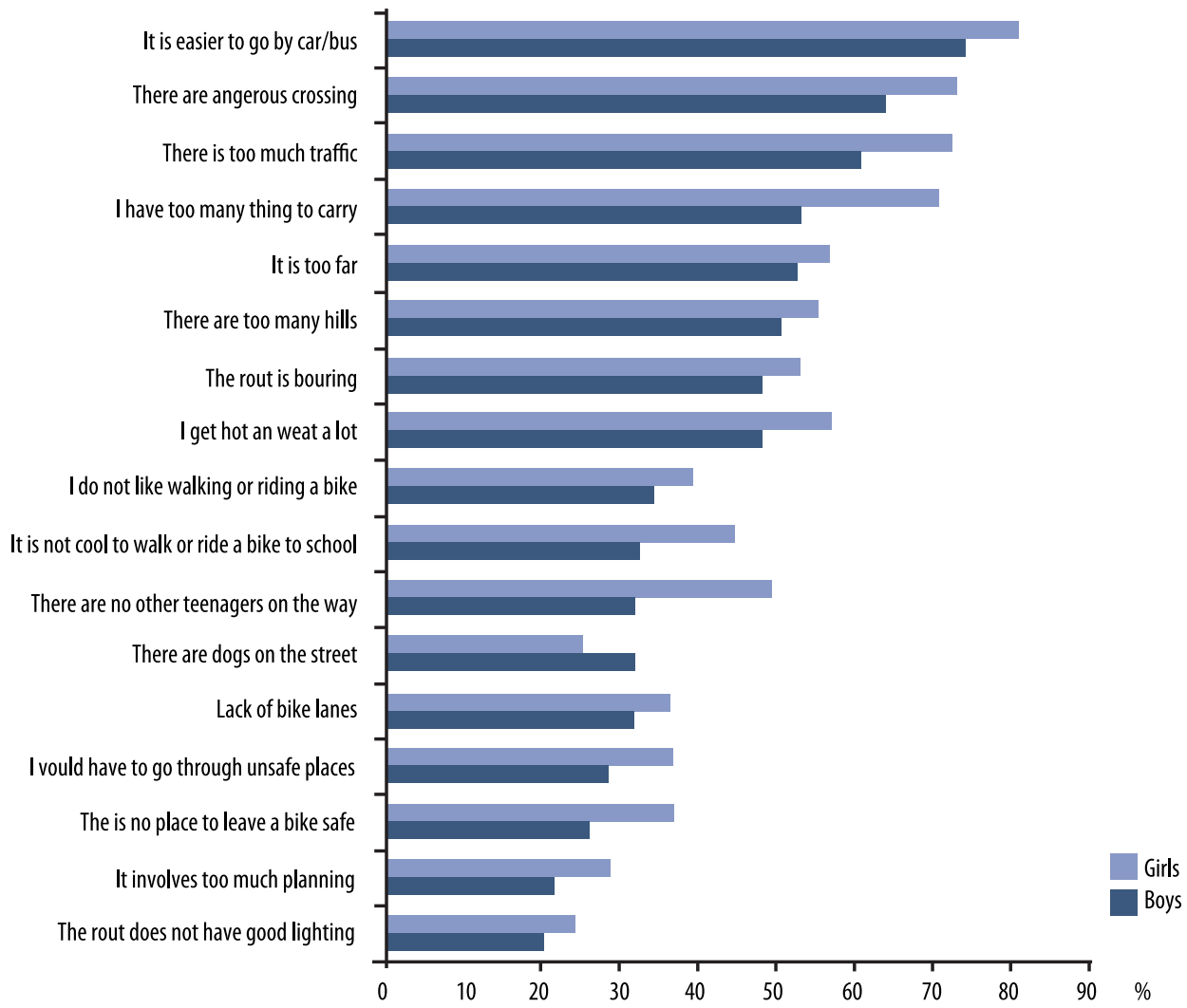

FIGURE 1 - Frequency of perceived barriers for active commuting to school. Curitiba, Brazil, 2012 $(n=741)$

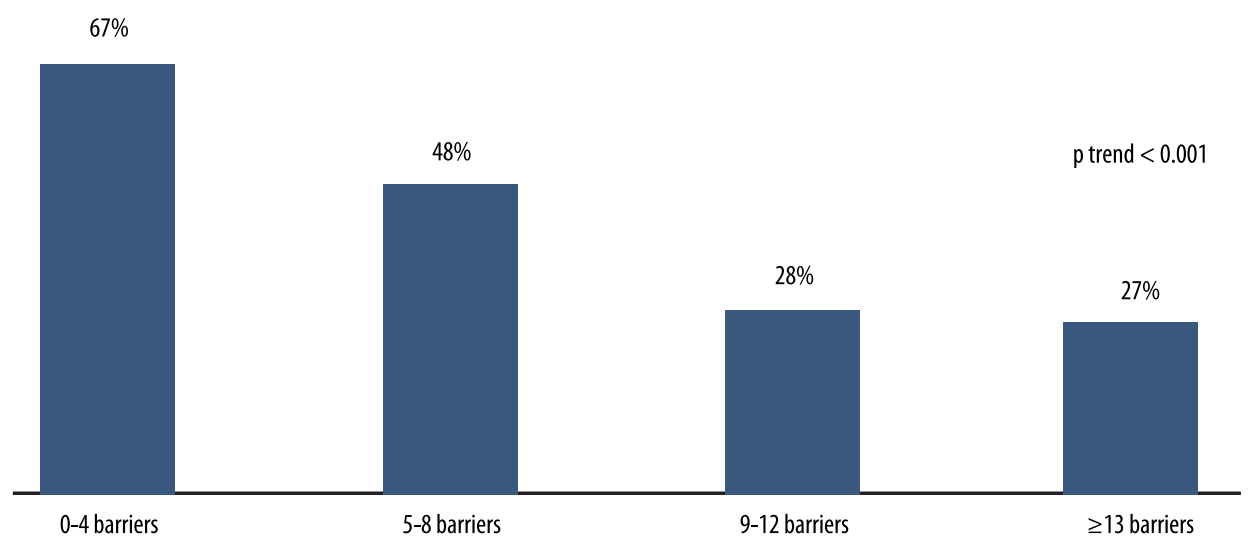

FIGURE 2 - Association between the number of perceived barriers and active commuting to school. Curitiba, Brazil, 2012 ( $\mathrm{n}=741)$ 
TABLE 2 - Association between perceived barriers and active commuting for boys. Curitiba, Brazil $2012(n=330)$.

\begin{tabular}{|c|c|c|c|c|c|c|c|}
\hline \multirow[t]{2}{*}{ Barriers } & \multirow[t]{2}{*}{ Presence } & \multicolumn{4}{|c|}{ Crude analysis } & \multicolumn{2}{|c|}{$\begin{array}{l}\text { Adjusted } \\
\text { analysis* }\end{array}$} \\
\hline & & $n$ & $\%$ & $P R$ & $95 \% \mathrm{Cl}$ & $P R$ & $95 \% \mathrm{Cl}$ \\
\hline \multirow[t]{2}{*}{ It is easier to go by car/bus } & No & 62 & 73.8 & 1 & & 1 & \\
\hline & Yes & 103 & 41.9 & 0,57 & $0.44-0.72$ & 0.80 & $0.58-1.11$ \\
\hline \multirow[t]{2}{*}{ There are dangerous crossings } & No & 64 & 54.2 & 1 & & 1 & \\
\hline & Yes & 101 & 47.5 & 0.88 & $0.70-1.10$ & 1.08 & $0.83-1.40$ \\
\hline \multirow[t]{2}{*}{ There is too much traffic } & No & 73 & 57.0 & 1 & & 1 & \\
\hline & Yes & 92 & 45.5 & 0.80 & $0.60-1.05$ & 1.27 & $1.04-1.56$ \\
\hline \multirow[t]{2}{*}{ I have too many things to carry } & No & 88 & 57.1 & 1 & & 1 & \\
\hline & Yes & 77 & 43.8 & 0.76 & $0.58-1.01$ & 0.99 & $0.83-1.18$ \\
\hline \multirow[t]{2}{*}{ It is too far } & No & 109 & 70.3 & 1 & & 1 & \\
\hline & Yes & 56 & 32.0 & 0.45 & $0.32-0.66$ & 0.71 & $0.60-0.86$ \\
\hline \multirow[t]{2}{*}{ There are too many hills } & No & 94 & 58.0 & 1 & & 1 & \\
\hline & Yes & 71 & 42.3 & 0.73 & $0.55-0.96$ & 0.88 & $0.71-1.08$ \\
\hline \multirow[t]{2}{*}{ The route is boring } & No & 85 & 50.0 & 1 & & 1 & \\
\hline & Yes & 80 & 50.0 & 1.00 & $0.79-1.27$ & 1.30 & $1.04-1.62$ \\
\hline \multirow[t]{2}{*}{ I get hot and sweat a lot } & No & 93 & 54.7 & 1 & & 1 & \\
\hline & Yes & 72 & 45.0 & 0.82 & $0.72-0.94$ & 1.02 & $0.81-1.29$ \\
\hline \multirow[t]{2}{*}{ I do not like walking or riding a bike } & No & 121 & 54.3 & 1 & & 1 & \\
\hline & Yes & 44 & 41.1 & 0.76 & $0.60-0.96$ & 0.87 & $0.63-1.20$ \\
\hline \multirow[t]{2}{*}{ It is not cool to walk or ride a bike to school } & No & 121 & 54.8 & 1 & & 1 & \\
\hline & Yes & 44 & 40.4 & 0.74 & $0.58-0.94$ & 0.95 & $0.71-1.28$ \\
\hline \multirow[t]{2}{*}{ There are no other teenagers on the way } & No & 113 & 52.3 & 1 & & 1 & \\
\hline & Yes & 52 & 45.6 & 0.87 & $0.71-1.06$ & 1.06 & $0.91-1.24$ \\
\hline \multirow[t]{2}{*}{ There are dogs on the street } & No & 119 & 53.1 & 1 & & 1 & \\
\hline & Yes & 46 & 43.4 & 0.87 & $0.57-1.17$ & 0.93 & $0.67-1.31$ \\
\hline \multirow[t]{2}{*}{ Lack of bike lanes } & No & 122 & 51.9 & 1 & & 1 & \\
\hline & Yes & 43 & 45.3 & 0.87 & $0.64-1.20$ & 0.97 & $0.75-1.27$ \\
\hline \multirow[t]{2}{*}{ I would have to go through unsafe places } & No & 132 & 54.3 & 1 & & 1 & \\
\hline & Yes & 33 & 37.9 & 0.70 & $0.52-0.94$ & 1.02 & $0.92-1.26$ \\
\hline \multirow[t]{2}{*}{ There is no place to leave a bike safe } & No & 118 & 52.7 & 1 & & 1 & \\
\hline & Yes & 47 & 44.3 & 0.84 & $0.62-1.14$ & 0.90 & $0.72-1.10$ \\
\hline \multirow[t]{2}{*}{ It involves too much planning } & No & 140 & 54.3 & 1 & & 1 & \\
\hline & Yes & 25 & 34.7 & 0.64 & $0.44-0.91$ & 0.90 & $0.60-1.34$ \\
\hline \multirow[t]{2}{*}{ The route does not have good lighting } & No & 133 & 50.8 & 1 & & 1 & \\
\hline & Yes & 32 & 47.1 & 0.93 & $0.54-1.60$ & 0.98 & $0.69-1.40$ \\
\hline
\end{tabular}

PR: prevalence ratio; 95\%Cl: interval with 95\% confidence; *adjusted for covariables presenting p $\leq 0.20$ (age, physical activity, perceived distance to school and schooling of a parent/responsible) + barriers presenting a significant association with active commuting in crude analysis ("It is easier to go by car/bus","It is too far", "There are too many hills", "I get hot and sweat a lot"', do not like walking or riding a bike,", "I is not cool to walk or ride a bike to school','I would have to go through unsafe places", "It involves too much planning"). 
TABLE 3 - Association between perceived barriers and active commuting to school for girls. Curitiba, Brazil $2012(n=441)$.

\begin{tabular}{|c|c|c|c|c|c|c|c|}
\hline \multirow{2}{*}{ Barriers } & \multirow{2}{*}{ Presence } & \multicolumn{4}{|c|}{ Crude analysis } & \multicolumn{2}{|c|}{ Adjusted analysis* } \\
\hline & & $n$ & $\%$ & $P R$ & $95 \% \mathrm{Cl}$ & $P R$ & $95 \% \mathrm{Cl}$ \\
\hline \multirow[t]{2}{*}{ It is easier to go by car/bus } & No & 55 & 69.6 & 1 & & 1 & \\
\hline & Yes & 98 & 29.5 & 0.42 & $0.33-0.54$ & 0.70 & $0.56-0.88$ \\
\hline \multirow[t]{2}{*}{ There are dangerous crossings } & No & 56 & 50.9 & 1 & & 1 & \\
\hline & Yes & 97 & 32.2 & 0.63 & $0.38-1.04$ & 1.00 & $0.77-1.29$ \\
\hline \multirow[t]{2}{*}{ There is too much traffic } & No & 53 & 46.9 & 1 & & 1 & \\
\hline & Yes & 100 & 33.6 & 0.72 & $0.51-1.00$ & 1.23 & $0.82-1.84$ \\
\hline \multirow[t]{2}{*}{ I have too many things to carry } & No & 59 & 48.8 & 1 & & 1 & \\
\hline & Yes & 94 & 32.4 & 0.66 & $0.53-0.84$ & 1.04 & $0.92-1.18$ \\
\hline \multirow[t]{2}{*}{ It is too far } & No & 101 & 56.7 & 1 & & 1 & \\
\hline & Yes & 52 & 22.3 & 0.40 & $0.31-0.50$ & 0.86 & $0.61-1.18$ \\
\hline \multirow[t]{2}{*}{ There are too many hills } & No & 81 & 44.0 & 1 & & 1 & \\
\hline & Yes & 72 & 31.7 & 0.72 & $0.47-1.11$ & 0.99 & $0.65-1.49$ \\
\hline \multirow[t]{2}{*}{ The route is boring } & No & 76 & 42.9 & 1 & & 1 & \\
\hline & Yes & 77 & 32.9 & 0.77 & $0.53-1.10$ & 1.16 & $0.88-1.52$ \\
\hline \multirow[t]{2}{*}{ I get hot and sweat a lot } & No & 93 & 48.2 & 1 & & 1 & \\
\hline & Yes & 60 & 27.5 & 0.57 & $0.41-0.80$ & 0.91 & $0.70-1.20$ \\
\hline \multirow[t]{2}{*}{ I do not like walking or riding a bike } & No & 96 & 46.2 & 1 & & 1 & \\
\hline & Yes & 57 & 28.1 & 0.61 & $0.42-0.88$ & 0.79 & $0.48-1.30$ \\
\hline \multirow[t]{2}{*}{ It is not cool to walk or ride a bike to school } & No & 94 & 41.2 & 1 & & 1 & \\
\hline & Yes & 59 & 32.2 & 0.78 & $0.55-1.10$ & 1.23 & $0.73-2.04$ \\
\hline \multirow[t]{2}{*}{ There are no other teenagers on the way } & No & 102 & 40.8 & 1 & & 1 & \\
\hline & Yes & 51 & 31.7 & 0.77 & $0.61-0.99$ & 0.96 & $0.80-1.17$ \\
\hline \multirow[t]{2}{*}{ There are dogs on the street } & No & 105 & 40.1 & 1 & & 1 & \\
\hline & Yes & 48 & 32.2 & 0.80 & $0.65-0.99$ & 1.06 & $0.87-1.30$ \\
\hline \multirow[t]{2}{*}{ Lack of bike lanes } & No & 99 & 38.1 & 1 & & 1 & \\
\hline & Yes & 54 & 35.8 & 0.94 & $0.71-1.25$ & 0.95 & $0.76-1.21$ \\
\hline \multirow[t]{2}{*}{ I would have to go through unsafe places } & No & 118 & 45.4 & 1 & & 1 & \\
\hline & Yes & 35 & 23.2 & 0.51 & $0.19-1.39$ & 0.78 & $0.31-1.91$ \\
\hline \multirow[t]{2}{*}{ There is no place to leave a bike safe } & No & 114 & 37.0 & 1 & & 1 & \\
\hline & Yes & 39 & 37.9 & 1.02 & $0.78-1.35$ & 1.06 & $0.90-1.23$ \\
\hline \multirow[t]{2}{*}{ It involves too much planning } & No & 132 & 44.9 & 1 & & 1 & \\
\hline & Yes & 21 & 17.9 & 0.40 & $0.27-0.60$ & 0.60 & $0.42-0.86$ \\
\hline \multirow[t]{2}{*}{ The route does not have good lighting } & No & 119 & 38.1 & 1 & & 1 & \\
\hline & Yes & 34 & 34.3 & 0.90 & $0.61-1.31$ & 1.00 & $0.70-1.40$ \\
\hline
\end{tabular}

PR: prevalence ratio; 95\% Cl: interval with 95\% confidence; *adjusted for covariables presenting p $\leq 0,20$. (age, physical activity, perceived distance to school and schooling of a parent/responsible) + barriers presenting a significant association with active commuting in crude analysis ("It is easier to go by car/bus'"'I have too many things to carry", "It is too far", "I get hot and sweat a lot", "I do not like walking or riding a bike," "There are no other teenagers on the way",'There are dogs on the street").

\section{Discussion}

The results this study indicate that only $42.9 \%$ (50.0\% in boys and $37.2 \%$ in girls) of students commute by walk or bike to or from school, with greater frequency among boys $(\mathrm{p}<0.05)$. The prevalence of active commuting was lower than compared to developed countries ${ }^{3,4,21}$ and to others cities of Brazil ${ }^{13,19,22}$. Comparison with 
other studies is undermined due to sample frame and size. The sample used in this study is not representative of adolescents from Curitiba as the design (private vs. public without proportionality) may have led to bias selection. Additionally, contextual factors could also help explaining such inconsistency. For instance, a study performed in South Brazil showed that the low prevalence of adolescents in active commuting is connected to work related activities after the school period ${ }^{5}$.

Overall, girls reported perceived barriers to active commuting more often than boys. The only barrier more prevalent among boys was "there is no place to leave a bike safe", which might be explained by the higher level of active commuting among boys. As boys are more frequently exposed to all barriers while they commute, hence a reversed causal relation is likely to be present in this finding. Nonetheless, a positive association between number of perceived barriers and active commuting was observed. In the literature there are no reports of girls perceiving more barriers. However, a study in Brazil identified that girls report more often barriers for overall physical activity ${ }^{18}$ and showed a positive association between number of barriers and overall physical activity physical activity among adults ${ }^{23}$.

Moreover, other studies showed that perceptions of neighborhood safety are associated with active commuting in girls ${ }^{24}$ and in adolescents with lower self-efficacy for physical activity ${ }^{25}$. Characteristics of the neighborhood such as residential density ${ }^{26}$, street connectivity ${ }^{8}$, presence of sidewalks ${ }^{7,24,25}$, mixed land use $\mathrm{e}^{7}$ are associated with active commuting.

After adjusting for confounders, two barriers remained associated with active commuting in girls "Easier to go by car/bus", "It involves too much planning", Access to car or bus is somehow an unexpected finding. However, Curitiba has been worldwide recognized for providing greater access to public transportation ${ }^{27}$, whereas experiencing a rapid grow on the private car fleet ${ }^{25}$. These characteristics combined with the high population density, increases the likelihood of a multimodal transportation ${ }^{28}$. Hence, people may walk to the nearest bus station or parking lot, which might help explain our findings ${ }^{28}$. The need for too much planning is likely to be associated to the distance to $\mathrm{school}^{5,8}$, period of studies and place of residence $^{21}$. Additionally, motivational and environmental barriers for overall physical activity ${ }^{18}$ have been reported among girls, somehow supporting our findings.

Among boys, three barriers remain associated after adjusting for confounding. The barrier "Is too far", has been found to be associated with active commuting in other studies ${ }^{2,5,8}$. Additionally, adolescents living on a distance are more likely to walk, whereas those residing up to eight kilometers distant are more likely to bicycling to school ${ }^{4}$. The available literature and our findings support the hypothesis that distance to school is a strong predictor of active commuting. The barriers, "Too much traffic" and "The route is boring" may be related to reversed causality as boys may perceived the traffic to be intense or not having fun while commuting to school though such characteristics do not prevent them to walk or cycle to school. However, improvements around the school such as safety, traffic and signs have been considered an effective strategy to promote active commuting ${ }^{29,30}$. Hence, higher levels of active commuting are likely to be found if such conditions are improved.

This study has limitations that should be considered. The cross-sectional design prevents causal inference though we have accounted for the main confounders. The sample was not representative of the city limiting external validity but the sample size was adequate to detect small effect sizes. The selection of the schools accounted for socioeconomic and geographic variation, however a sample bias is 
nor prevented as we did not include school located in areas of intermediated income level. Additionally, only a single self-reported question was used to describe active commuting, hence a potential misclassification cannot be excluded as a potential bias. Although a mismatch between perceived and actual environment is expected we examined environmental and social characteristics (e.g. heavy traffic, aesthetics and perceived access) that have been consistently linked to physical activity outcomes, and using standardized and valid measures. Nonetheless, further examination on the importance of actual and objectively measured environment on active commuting is needed.

In conclusion, the association barriers were "Easier to go by car/bus", "It involves too much planning", (for girls) and "Too far", "Too much traffic" and "The route is boring" (for boys). The results of this study have significant contributions. We found that active commuting among adolescents is low that environmental and psychological barriers associated with this behavior varied by gender. Efforts to promote active commuting should consider gender specific actions such as providing safe routes maps and organizing group activities and finding faster routes. Additionally, improvement on traffic signage and enforcing existing traffic regulations will help increasing safety for active commuting.

\section{Acknowledgements}

The authors thank the members of Physical Activity and Quality of Life Research Group (GPAQ) for their help in data collection.

\section{Contribution of authors}

L. A. Becker collaborated on the data collected, was responsible for the initial conception of this study, analysis and interpretation of data, literature review, initial and final writing of article. R.C. Fermino collaborated on the data collected, was responsible for the conception of this study, analysis and interpretation of data, and drafting and critical review of the text in all stages. A.V. Lima participated in the planning phase, was responsible for the data collected and initial writing of the article. C.R. Rech was responsible for the planning phase, data collected and drafting and critical review of the text in all stages. C.R.R. Añez participated in the planning and critical review of the article. R.S. Reis participated in the study concept, planning and writing and critical review of the article. All the authors read approved the final version of the manuscript.

\section{References}

1. Hallal PC, Andersen LB, Bull FC, Guthold R, Haskell W, Ekelund U. Global physical activity levels: surveillance progress, pitfalls, and prospects. The Lancet. 2012;380(9838):247-57.

2. Wong BY-M, Faulkner G, Buliung R. GIS measured environmental correlates of active school transport: a systematic review of 14 studies. Int J Behav Nutr Phys Act. 2011;8:39.

3. BabeySH, Hastert TA, Huang W, Brown ER. Sociodemographic, family, and environmental factors associated with active commuting to school among US adolescents. J PublicHealth Policy. 2009;30(Suppl 1):203-20.

4. Van Dyck D, De Bourdeaudhuij I, Cardon G, Deforche B. Criterion distances and correlates of active transportation to school in Belgian older adolescents. Int J Behav Nutr Phys Act. 2010;7(1):7:87

5. Silva KS, da Silva Lopes A, Hardman CM, Cabral LG, da Silva SG, Nahas MV. Commuting to school and to work among high school students in Santa Catarina State, Brazil: A comparative analysis between 2001 and 2011. J Phys Act Health. 2014;11(8):1458-67.

6. Silva KS, Nahas MV, Borgatto AF, Oliveira ES, Del Duca GF, Lopes AS. Factors associated with active commuting to school and to work among brazilian adolescents. J Phys Act Health. 2011;8(7):926-33. 
7. Van Dyck D, Cardon G, Deforche B, De Bourdeaudhuij I. Lower neighbourhood walkability and longer distance to school are related to physical activity in Belgian adolescents. Prev Med. 2009;48(6):516-8

8. De Meester F, Van Dyck D, De Bourdeaudhuij I, Deforche B, Cardon G. Does the perception of neighborhood built environmental attributes influence active transport in adolescents? Int J Behav Nutr Phys Act. 2013;10(1)10:38.

9. Lu W, McKyer ELJ, Lee C, Goodson P, Ory MG, Wang S. Perceived barriers to children's active commuting to school: a systematic review of empirical, methodological and theoretical evidence. Int J Behav Nutr Phys Act. 2014;11(1):1-20.

10. Herrador-Colmenero M, Pérez-García M, Ruiz JR, Chillón P. Assessing modes and frequency of commuting to school in youngsters: A systematic Review. Pediatr Exerc Sci. 2014;26(3):291-341.

11. Arango CM, Parra DC, Eyler A, Sarmienteo O, Mantilla SC, Gomes LF, et al. Walking or bicycling to school and weight status among adolescents from Montería, Colombia. J Phys Act Health. 2011;8(Suppl 2):171-7.

12. Costa FF, Silva KS, Schmoelz CP, Campos VC, de Assis MA a. Longitudinal and crosssectional changes in active commuting to school among Brazilian schoolchildren. Prev Med. 2012;55(3):212-4.

13. Silva KS, Vasques DG, Martins CDO, Williams LA, Lopes AS. Active commuting: prevalence, barriers, and associated variables. J Phys Act Health. 2011;8(6):750-7.

14. Reis RS, Hino AAF, Parra DC, Hallal PC, Brownson RC. Bicycling and walking for transportation in three Brazilian cities. Am J Prev Med. 2013;44(2):9-17.

15. Lima AV. Validade e fidedignidade de um instrumento para avaliar a características do bairro para atividade física em adolescentes: versão brasileira do neighborhood environment walkability scale for youth [dissertação de mestrado]. Paraná: Universidade Federal do Paraná; 2013.

16. Hume C, Timperio A, Salmon J, Carver A, Giles-Corti B, Crawford D. Walking and cycling to School. Predictors of increases among children and adolescents. Am J Prev Med. 2009;36(3):195-200.

17. Lima AV, Rech CR, Reis RS. Semantic, item, and conceptual equivalence of the Brazilian version of the Neighborhood Environment Walkability Scale for Youth (NEWS-Y). Cad Saude Publica. 2013;29(12):2547-53.

18. Santos MS, Fermino RC, Reis RS, Cassou AC, Rodriguez-Añez CR. Barries related to physical activity practice in adolecents. a focus-group study. Rev Bras Desempenho Hum. 2010;12(3):137-43.

19. Santos CM, Wanderley Júnior RDS, Barros SSH, Farias Júnior JC, Barros MVG. Prevalenc of physical inactivity and associeted factors among adolecents commuting school. Cad Saude Publica. 2010;26(7):1419-30

20. World Health Organization. Global Physical Activity Questionnaire (GPAQ) Analysis Guide. 2012. Mar 10-20. Disponível: http:// www.who.int/chp/steps

21. Wong BY-M, Faulkner G, Buliung R, Irving H. Mode shifting in school travel mode: examining the prevalence and correlates of active school transport in Ontario, Canada. BMC Public Health. 2011;11(1):618.

22. Bacil E, Rech C, Hino A. Physical activity patterns among high school students of Ponta Grossa, PR. Rev Bras Ativ Fís Saúde. 2013;18(2):177-85.

23. Reichert FF, Barros AJD, Domingues MR, Hallal PC. The role of perceived personal barriers to engagement in leisure-time physical activity. Am J Prev Med. 2007;97(3):515- 19.

24. Evenson KR, Birnbaum AS, Rung ALB, Sallis JF, Voorhess CC, Ring K, et al. Girls' perception of physical environmental factors and transportation: reliability and association with physical activity and active transport to school. Int J Behav Nutr Phys Act. 2007;3:28.

25. Deforche B, Dyck DV, Verloigne M, Bourdeaudhuij ID. Perceived social and physical environmental correlates of physical activity in older adolescents and the moderating effect of self-efficacy. Prev Med. 2010;50(Suppl 1):524-9.

26. Dalton MA, Longacre MR, Drake KM, Gibson L, Adachi-Mejia AM, et al. Built environment predictores of active travel to school among rural adolescents. Am J Prev Med. 2011;40(3):312-9. 
27. Dyck DV, Gardon G, Deforche B, Bourdeaudhuij ID. Lower neighbourhoord walkability and longer distance to school are related to physical activity in belgian adolescents. Prev Med. 2009;48(6):516-8

28. Becerra JM, Reis RS, Frank LD, Ramirez-Marrero FA, Welle B, Arriaga Cordero E et al. Transport and health: a look at three Latin American cities. Cad Saude Publica. 2013;29(4):654-66.

29. Santos MS, Hino AAF, Reis RS, Anez CRR. Prevalenc of barriers for physical activity in adolecents. Rev Bras Epidemiol. 2010;13(1):94-104.

30. Yang Y, Diez-Roux A V. Using an agent-based model to simulate children's active travel to school. Int J Behav Nutr Phys Act. 2013; 10(1): 67

Corresponding

Author

Leonardo Augusto Becker

leonardobecker26@hotmail.com

Pontifical University Catholic of Paraná. Life

Sciences School. Research Group in Physical

Activity and Quality of Life (GPAQ). Rua

Imaculada Conceição. 1155 - Prado Velho -

80215-901-Curitiba-PR. Brazil.

Phone number: + 554132712503

REceived

Revised

$25 / 02 / 2016$

Approved

$28 / 10 / 2016$ 